\title{
ANALISIS PENETAPAN HARGA JUAL DALAM MENINGKATKAN LABA PADA RUMAH MAKAN ULU BETE LAUT DI MASAMBA KABUPATEN LUWU UTARA
}

\author{
I Ketut Patra' \\ Agus Salim²
}

No. HP $081355106244^{1}$

\section{ABSTRAK}

Tujuan penelitian adalah untuk mengetahui dan menganalisis Penetapan Harga Jual Dalam Meningkatkan Laba Pada Rumah Makan Ulu Bete Laut Di Masamba Kabupaten Luwu. Metode analisis data yang dipergunakan dalam penelitian ini adalah Metode Cost Plus Pricing, yaitu penetapan harga jual dengan menambah margin (keuntungan) yang digunakan pada biayabiaya yang telah dibebankan pada barang. Hasil penelitian pengujian hipotesis yaitu Hasil analisis harga pokok produk menunjukkan nilai yang rendah di tambah laba yang diharapkan oleh pemilik RM Ulu Bete Laut setiap bulan sebesar $50 \%$ per porsi untuk makanan per porsi dan 30\% per gelas untuk minuman buah segar.

Harga jual makanan per unit (per porsi) sebesar Rp 12.445 sedangkan realisasi harga makanan per porsi pada RM Ulu Bete Laut sebesar Rp 22.000,-. Dengan demikian penetapan harga jual sesungguhnya 200\% lebih dari harga pokok yang hanya mencapai Rp 8.297 per porsi.

Harga jual minuman segar sebesar Rp 8.723 per gelas. Realisasi harga yang berlaku pada RM Ulu Bete Laut sebesar Rp 10.000,per gelas. Dengan demikian terdapat kenaikan harga sekitar $140 \%$ dari harga pokok. Jika pemilik Rumah Makan (RM) Ulu Bete Laut tidak mencapai total penjualan di atas, maka dipastikan akan mengurangi jumlah laba usaha dan bahkan dapat menderita kerugian. Hasil analisis profitabilitas pertama berdasarkan data rincian pendapatan, sehingga diperoleh rasio profitabilitas sebesar 30,94\% per bulan, artinya bahwa setiap penjualan Rp 100,- mampu memberikan laba usaha sebesar Rp 30,94 per unit.

Berdasarkan data harga pokok produk yang dipakai sebagai dasar perhitungan hasil penjualan. Besarnya laba yang diperoleh RM Ulu Bete Laut setiap bulan, dapat dihitung diselisihkan antara hasil penjualan dengan harga pokok. Harga pokok produk yang dipakai sebagai dasar perhitungan harga jual, di peroleh laba usaha sebesar 15,23\%, artinya bahwa setiap penjualan Rp 100,mampu memberikan laba usaha sebesar Rp 15,23 per unit.

\section{Kata Kunci: Harga Jual dan Laba}

\section{PENDAHULUAN}

Teori ekonomi mikro menjelaskan bahwa bisnis sebagai penggerak sosial ekonomi secara keseluruhan. Semakin banyak kegiatan bisnis suatu daerah, semakin besar peluang daerah tersebut mengalami kemajuan di segala aspek kehidupan. Kegiatan bisnis menjadi penyedia lapangan kerja bagi masyarakat yang memiliki waktu dan keterampilan. Bisnis akan menghasilkan barang atau jasa guna memenuhi kebutuhan manusia yang tidak terbatas dan berlangsung terus menerus. Sedangkan faktor-faktor ekonomi yang menghasilkan barang atau jasa sangatlah terbatas. Dengan demikian pelaku bisnis termotivasi untuk beroperasi guna 
memenuhi kebutuhan masyarakat yang semakin kompleks.

Sebelum perusahaan dilaksanakan, maka studi kelayakan bisnis tersebut harus dianalisis untuk mengetahui kelayakannya. Tujuannya adalah untuk meminimalkan resiko kerugian. Investasi menunjukkan bahwa usaha ditentukan oleh jenis produk atau jasa yang sangat dibutuhkan oleh anggota masyarakat. Jika investasi yang diusulkan layak secara ekonomis, maka lembaga pembiayaan (Bank) bersedia memberikan kredit untuk modal kerja dan modal investasi sesuai kebutuhan. Modal harus dimanfaatkan secara efisien, penggunaan modal yang sesuai dengan kebutuhan akan menghasilkan laba yang optimal.

Suatu kegiatan bisnis yang dijalankan, tentulah memiliki tujuan yang ingin dicapai oleh pemilik dan manajemen agar tetap tetap hidup (survive). Perusahaan menginginkan keuntungan yang optimal atas usaha yang dijalankannya karena pemilik perusahaan menginginkan modal yang telah ditanamkan dalam usahanya segera cepat kembali juga mengharapkan adanya hasil atas modal yang ditanamkannya sehingga mampu memberikan tambahan modal dan kemakmuran bagi pemilik dan seluruh karyawannya.

Bagi perusahaan, laba yang diperoleh merupakan pencapaian rencana (target) yang telah ditentukan sebelumnya. Pencapaian target laba sangat penting karena dengan memperoleh laba yang telah ditetapkan atau bahkan melebihi target yang diinginkan akan memberikan kepuasan tersendiri bagi pemilik perusahaan. Kondisi ini merupakan ukuran keberhasilan dan kesuksesan untuk menilai kinerja manajemen dalam mengelola perusahaan. Demikian pula sebaliknya, apabila perusahaan gagal mencapai target, maka cermin ketidak-mampuan atau terjadi kegagalan manajemen dalam mengelola perusahaan.

Selain memperoleh laba, perusahaan juga menginginkan agar kegiatan bisnis yang dijalankan tidak hanya untuk satu periode saja, tetapi pemilik perusahaan menginginkan memiliki umur panjang untuk beberapa periode kedepan. Bahkan bila perlu pemilik menginginkan usaha yang dijalankan hidup dan berkembang secara kontinyu.

Tujuan lain yang ingin dicapai perusahaan yaitu tetap mampu menghasilkan atau menyediakan berbagai jenis produk/jasa untuk kepentingan masyarakat umum. Ketersediaan produk/jasa yang mampu memberikan kemakmuran bagi masyarakat, maka pemilik perusahaan akan meningkatkan kemakmuran pemegang saham dan manajemen serta karyawan perusahaan yang bersangkutan.

Jika perusahaan bekerja secara optimal dan efisien, maka produk yang dihasilkan mampu bersaing dipasar yang mampu menguasai pasar, sehingga volume produksi akan ditambah sesuai pangsa pasar yang dikuasai. Dengan demikian perusahaan akan menambah tenaga kerja produktif dan memperoleh pendapatan. Bertambahnya pendapatan masyarakat akan mendorong daya beli. Semakin besar permintaan 
masyarakat terhadap produk, maka peluang untuk menambah investasi baru. Ditinjau dari aspek pemerataan, perusahaan kecil juga mempunyai peran yang sangat penting karena dapat menunjang program pemerataan kesempatan untuk berusaha, pemerataan dalam penyebaran lokasi bisnis di daerah dan pemerataan dalam peningkatan pendapatan atau kesejahteraan masyarakat melalui kesempatan kerja.

Semakin kompleksnya kegiatan suatu perusahaan atau industri disebabkan karena kegiatan perekonomian dan pembangunan di Indonesia semakin berkembang. Sebuah industri yang telah melaksanakan produksi barang dan jasa dalam jumlah besar dengan maksud untuk memenuhi permintaan konsumen di pasar. Terjadinya persaingan yang semakin serius akan menuntut banyak perusahaan sejenis berupaya untuk menguasai pasar sasaran.

Untuk maksud tersebut, total biaya per unit suatu produk harus dihitung dengan cermat agar dapat menentukan harga jual yang tepat terhadap produk yang dihasilkan. Dengan demikian, harga pokok produk menggambarkan biaya minimal yang harus diterima kembali oleh produsen. Harga jual produk merupakan salah satu instrument bagi pemilik perusahaan untuk meningkatkan laba yang optimal guna menambah modal usaha.

Dengan adanya penetapan harga jual sesuai biaya sesungguhnya, maka produk yang dihasilkan dapat bersaing di pasar, bahkan mampu memimpin pasar dan menguasai pasar sasaran. Penetapan harga jual disesuaikan dengan daya beli konsumen (masyarakat). Penetapan harga jual yang tidak tepat, akan dapat berpengaruh negatif terhadap laba perusahaan.

Setiap aktivitas bisnis selalu mengharapkan laba yang optimal pada waktu tertentu. Sedangkan kenyataannya selalu berbeda dengan harapan sesuai rencana yang ditetapkan, sehingga terjadi kesenjangan atau masalah yang harus diselesaikan.

\section{METODE PENELITIAN}

Dalam penelitian ini diperlukan data yang relevan dengan objek yang diteliti dalam rangka pengumpulan data, maka penulis mengadakan penelitian pada rumah makan Ulu Bete Laut di Masamba Kabupaten Luwu Utara. Adapun jenis data yang digunakan dalam penelitian ini adalah data kualitatif dan data kuantitatif yang bersumber dari data primer dan data sekunder. Metode pengumpulan data yang digunakan yaitu observasi, wawancara, dan dokumentasi.

\section{Metode Analisis Data}

Dalam menganalisis data, metode yang digunakan dalam penetapan harga jual adalah Metode cost plus pricing, yaitu penetapan harga jual dengan menambah margin (keuntungan) yang digunakan pada biaya-biaya yang telah dibebankan pada barang, dengan rumus :

Total Cost (TC) = VC + FC

Profit Margin $\quad=($ TC $\times \ldots \%$ Laba $)$ 
Harga Jual $(\mathrm{HJ}) \quad=\mathrm{TC}+$ Profit Margin

Keterangan :
FC = Biaya Tetap

Margin = Laba yang diinginkan

TC = Total biaya per unit

VC = Biaya variabel

Pembahasan Hasil Penelitian

Tabel 1

Jenis Biaya Variabel pada Rumah Makan Ulu Bete Laut

\begin{tabular}{|c|l|c|c|c|}
\hline No. & Jenis Biaya Variabel & Hari (Rp) & Bulan & Total Biaya \\
\hline 1 & Bahan Baku Makanan & 1.520 .000 & 30 hari & Rp 45.600 .000 \\
\hline 2 & Bahan minuman segar & 1.000 .000 & 30 hari & 30.000 .000 \\
\hline 3 & Tenaga kerja langsung & -- & 30 hari & 20.000 .000 \\
\hline 4 & Gas elpiji (tabung gas) & 120.000 & 30 hari & 3.600 .000 \\
\hline \multicolumn{2}{|r|}{ Total Biaya Variabel } & Rp 99.200.000 \\
\hline
\end{tabular}

Sumber: Data Rumah Makan Ulu Bete Laut Masamba, April 2014

Total biaya variabel yang dikeluarkan oleh Rumah Makan Ulu Bete Laut per bulan sebesar Rp 99.200.000,-. Biaya variabel tersebut terdiri atas biaya bahan baku- masakan dan bahan minuman segar, biaya tenaga kerja langsung (karyawan), biaya tabung gas elpiji (biaya overhead), dan biaya lainnya.

Tabel 2

Jenis Biaya Variabel pada Rumah Makan Ulu Bete Laut

\begin{tabular}{|l|l|r|r|r|}
\hline No. & Jenis Aset Tetap & Harga (Rp) & Umur & \multicolumn{1}{l|}{ By penyusutan } \\
\hline 1 & Gedung RM Ulu Bete & 200.000 .000 & 20 thn & Rp 10.000 .000 \\
\hline 2 & Peralatan masak & 20.000 .000 & 2 thn & 10.000 .000 \\
\hline 3 & Meja dan kursi & 10.000 .000 & 2 thn & 5.000 .000 \\
\hline 4 & Kompor elpiji & 2.000 .000 & 1 thn & 2.000 .000 \\
\hline 5 & Motor bebek & 15.000 .000 & 5 thn & 3.000 .000 \\
\hline \multicolumn{2}{|l|}{ Total Biaya Tetap } & & $\mathbf{R p ~ 3 0 . 0 0 0 . 0 0 0}$ \\
\hline
\end{tabular}

Sumber: Data Rumah Makan Ulu Bete Laut Masamba, April 2014 
Total biaya tetap terdiri atas biaya penyusutan asset tetap dan air minum dari PDAM sebesar Rp 30.000.000,- per tahun atau per bulan sebesar Rp 2.500.000,- per bulan.

Gedung rumah makan ulu bête laut didirikan pada tahun 2000 dengan total dana investasi Rp 200 juta. Peralatan untuk masak terdiri atas belangan/panci besar, kuali besar, piring, mangkok, sendok, gelas, dan berbagai macam peralatan lainnya.

1. Penetapan harga pokok

Perhitungan harga pokok produk berdasarkan total biaya variabel ditambah total biaya tetap dibagi jumlah unit produk yang dihasilkan selama satu periode tertentu (satu bulan). Diketahui total biaya bahan baku setiap bulan, yaitu belanja bahan baku per bulan sebesar $\mathrm{Rp}$ $1.520 .000 \times 30$ hari $=\operatorname{Rp~45.600.000,-~}$ per bulan.

2. Rasio Laba

Berdasarkan hasil perhitungan biaya variabel dan biaya tetap tersebut di atas, untuk menghasilkan menu makanan dan minuman segar, maka dapat diketahui besarnya Harga Pokok Produk (HPP) dan Harga Jual dengan menggunakan rumus sebagai berikut:

Harga Jual $(\mathrm{HJ})=$ HPP $+(\%$ Profit $x$ HPP $)$.

Diketahui biaya variabel masing-masing produk, sebagai berikut:

Bahan baku makanan $=\operatorname{Rp~45.600.000,-~}$

Bahan baku minuman $=\operatorname{Rp} 30.000 .000$,-

Tenaga kerja langsung=Rp 20.000.000,-

Gas elpiji (tabung gas)= Rp 3.600.000,-
Total biaya variabel(VC...... Rp 99.200.000,Harga pokok bahan dan tenaga kerja langsung menjadi dasar perhitungan laba operasi. Sedangkan laba bersih diperoleh setelah harga jual dikurangi dengan total biaya tetap dan biaya bunga serta pajak penghasilan.

Berdasarkan perhitungan total biaya tetap dapat dihitung sebagai berikut:

Gaji manajer per bulan = Rp 3.000.000,-

Gaji security per bulan = Rp 1.000.000,-

Penyusutan asset tetap $=R p$ 2.500.000,-

Biaya listrik per bulan $=R p \quad 500.000$,-

Biaya PDAM per bulan = Rp 300.000,-

Biaya lain-lain per bulan $=\underline{R p ~ 200.0000,-}+$ Total biaya tetap (FC) ..... $=$ Rp 7.500.000,-

Harga pokok produk (HPP) diperoleh melalui penjumlahan biaya variable (VC) dan biaya tetap (FC). Dengan demikian, maka harga jual dapat dihitung sebagai berikut:

Total Cost $(\mathrm{TC})=\mathrm{VC}+\mathrm{FC}$

$$
\begin{aligned}
& =R p 99.200 .000+\text { Rp 7.500.000 } \\
& =R p 106.700 .000,-/ \text { Bulan }
\end{aligned}
$$

Profit Margin $(\mathrm{PM})=(\mathrm{TC} \times \mathrm{x}$... Laba $)$

$$
\begin{aligned}
& =(\operatorname{Rp~106.700.000\times 25\% )} \\
& =\operatorname{Rp~26.675.000,-/~Bulan~}
\end{aligned}
$$

Harga Jual $(\mathrm{HJ})=\mathrm{TC}+$ Profit Margin

$$
\begin{aligned}
& =\operatorname{Rp} 99.200 .000+\operatorname{Rp} 26.675 .000 \\
& =\operatorname{Rp} 125.875 .000,-/ \text { Bulan }
\end{aligned}
$$

Berdasarkan hasil analisis tersebut di atas, maka total penjualan yang diharapkan setiap bulan sebesar Rp125.875.000,-. Dari hasil penjualan tersebut terdapat biaya variabel, biaya tetap, dan tambahan laba yang diharapkan sebesar 25 persen. Jika pemilik Rumah Makan (RM) Ulu Bete Laut 
tidak mencapai total penjualan di atas, maka dipastikan akan mengurangi jumlah laba usaha, dan bahkan dapat menderita kerugian. Harga jual per unit dapat diketahui dengan cara membagi total harga jual per bulan dengan jumlah porsi makanan dan minuman yang terjual. Berdasarkan data pada tabel 03 menunjukkan jumlah porsi makanan lengkap yang terjual per hari sebanyak 275 porsi atau 8.250 porsi per bulan. Sedangkan jumlah minuman segar yang terjual per hari sebanyak 190 gelas atau 5.700 gelas per bulan (tabel 04).
Harga pokok per unit (satu porsi) untuk makanan dapat dihitung dengan menggunakan metode biaya bersama, yaitu biaya tenaga kerja per bulan dibebani $70 \% \mathrm{x}$ Rp 20.000.000= Rp 14.000.000,- dan untuk minuman 30\% $\times$ Rp 20.000.000 = Rp $6.000 .000,-$. Sedangkan total biaya tetap per bulan sebesar $\mathrm{Rp} 7.500 .000$,- dibebankan untuk makanan 70\% Rp 7.500.000= Rp $5.200 .000,-$ dan $30 \% \times R p 7.500 .000=R p$ 2.250.000,- dibebankan untuk minuman.

Berdasarkan data dan perhitungan di atas, maka jumlah biaya makanan dan minuman dapat di lihat dalam table 3 berikut:

Tabel 3

Jenis Biaya Variabel pada Rumah Makan Ulu Bete Laut

\begin{tabular}{|l|l|r|r|r|}
\hline No. & Jenis Biaya & Makanan & \multicolumn{1}{l|}{ Minuman } & \multicolumn{1}{|l|}{ Total } \\
\hline 1 & Bahan Makanan & 45.600 .000 & 30.000 .000 & 75.600 .000 \\
\hline 2 & Gas Elpiji & 3.600 .000 & -- & 3.600 .000 \\
\hline 3 & Upah Tenaga Kerja & 14.000 .000 & 6.000 .000 & 20.000 .000 \\
\hline 4 & Biaya Tetap & 5.250 .000 & 2.250 .000 & 7.500 .000 \\
\hline \multicolumn{2}{r|}{ Total biaya } & 68.450 .000 & 38.250 .000 & 106.700 .000 \\
\hline
\end{tabular}

Sumber: Data Rumah Makan Ulu Bete Laut Masamba, April 2014

Berdasarkan data tersebut di atas, maka dapat di analisis harga pokok dan harga jual per unit (per porsi untuk makanan dan per gelas untuk minuman segar), sebagai berikut: 
1. Harga Pokok Produk (HPP) :

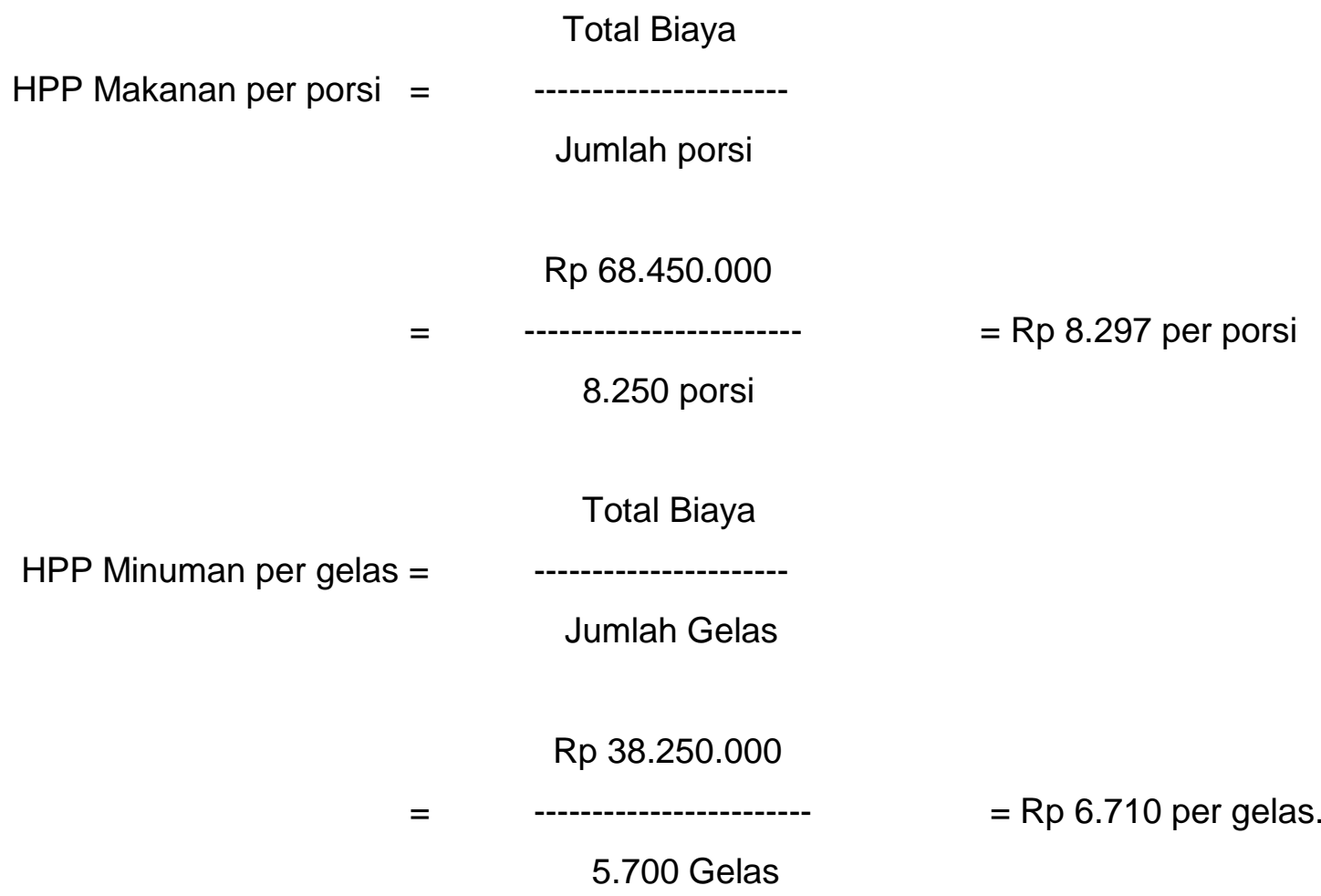

2. Harga Jual (HJ):

HJ Makanan per porsi

$$
\begin{aligned}
\text { HJ Makanan per porsi } & =\mathrm{HPP}+(50 \% \times \mathrm{HPP}) \\
& =\mathrm{Rp} 8.297+(50 \% \times \mathrm{Rp} 8.297) \\
& =\mathrm{Rp} 12.445 \text { per porsi } \\
\text { HJ Minuman per gelas } & =\mathrm{HPP}+(30 \% \times \mathrm{HPP}) \\
& =\mathrm{Rp} 6.710+(30 \% \times \mathrm{Rp} 6.710) \\
& =\mathrm{Rp} 8.723 \text { per gelas }
\end{aligned}
$$

Hasil analisis harga pokok produk menunjukkan nilai yang rendah di tambah laba yang diharapkan oleh pemilik RM Ulu Bete Laut setiap bulan sebesar $50 \%$ per porsi untuk makanan per porsi dan 30\% per gelas untuk minuman buah segar.
Harga jual makanan per unit (per porsi) sebesar Rp 12.445 sedangkan realisasi harga makanan per porsi pada RM Ulu Bete Laut sebesar Rp 22.000,-. Dengan demikian penetapan harga jual sesungguhnya 200\% lebih dari harga pokok yang hanya mencapai Rp 8.297 per porsi. 
Harga jual minuman segar sebesar Rp 8.723 per gelas. Realisasi harga yang berlaku pada RM Ulu Bete Laut sebesar Rp 10.000,per gelas. Dengan demikian terdapat kenaikan harga sekitar $140 \%$ dari harga pokok.
Untuk mengetahui besarnya laba yang diperoleh RM Ulu Bete Laut setiap bulan, maka dapat dihitung dengan membandingkan antara hasil penjualan yang peluang diterima dikurangi dengan harga pokok produk. Adapun laba yang diperoleh RM Ulu Bete Laut setiap bulan sebagai berikut:

Tabel 4

\section{Perhitungan Laba Rugi per Bulan pada Rumah Makan Ulu Bete Laut Berdasarkan Rincian Pendapatan.}

\begin{tabular}{|c|c|}
\hline Penjualan per bulan.......... & Rp 154.500 .000 \\
\hline Biaya Variabel . & Rp 99.200 .000 \\
\hline Kontribusi Margin. & $\mathrm{Rp} \quad 55.300 .000$ \\
\hline Biaya Tetap. & $\mathrm{Bp} \quad 7.500 .000$ \\
\hline Laba Usaha & $\mathrm{Rp} \quad 47.800 .000$ \\
\hline
\end{tabular}

Sumber:Data di olah dari Rumah Makan Ulu Bete Laut Masamba, April 2014

\section{Berdasarkan rincian perhitungan} pendapatan RM Ulu Bete Laut dikurangi biaya variabel dan biaya tetap, maka diperoleh laba usaha setiap bulan yang peluang diperoleh sebesar Rp 47.800.000,-. Sedangkan perhitungan penjualan berdasarkan harga- pokok di tambah persentase laba yang diharapkan sebesar $25 \%$, maka besarnya laba usaha yang dapat diperoleh setiap bulannya sebesar Rp 19.175.000,-. Lebih jelasnya dapat dilihat dalam table, sebagai berikut:

Tabel 5

Perhitungan Laba Rugi per Bulan pada Rumah Makan Ulu Bete Laut Berdasarkan Harga Pokok.

Penjualan per bulan

Biaya Variabel

Kontribusi Margin

Biaya Tetap

Laba Usaha
Rp 125.875.000

Rp 99.200.000

Rp 26.675.000

Rp $\quad 7.500 .000$

Rp 19.175 .000 
Berdasarkan data di atas, maka dapat dianalisis dengan menggunakan pendekatan rasio profitabilitas sebagai berikut:

$$
\begin{gathered}
\text { Laba Usaha } \\
\text { Profitabilitas }=\text {---------------- } \text { x 100\% } \\
\text { Penjualan }
\end{gathered}
$$$$
\text { Rp } 47.800 .000
$$

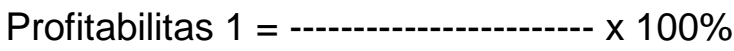

$$
\begin{aligned}
& \text { Rp } 154.500 .000 \\
= & 30,94 \%
\end{aligned}
$$

Hasil analisis profitabilitas pertama berdasarkan data rincian pendapatan, maka diperoleh rasio profitabilitas sebesar 30,94\% per bulan, artinya bahwa setiap penjualan $\mathrm{Rp}$ 100,- mampu memberikan laba usaha sebesar Rp 30,94 per porsi

Sedangkan hasil analisis profitabilitas ke dua dengan menggunakan data harga pokok produk yang diperhitungkan, maka dapat dihitung, sebagai berikut:

$$
\text { Rp } 19.175 .000
$$

Profitabilitas $2=$ $x 100 \%$

$$
\begin{aligned}
& R p 125.875 .000 \\
= & 15,23 \%
\end{aligned}
$$

Berdasarkan data harga pokok produk yang dipakai sebagai dasar perhitungan laba usaha, maka di peroleh sebesar 15,23\%, artinya bahwa setiap penjualan Rp 100,mampu memberikan laba usaha sebesar $\mathrm{Rp}$ 15,23 per porsi.

Ke dua bentuk formulasi perhitungan harga jual sama-sama memberikan kontribusi laba, namun terdapat perbedaan pada jumlah persentase labanya pada RM Ulu Bete Laut tetap memperoleh laba usaha.

\section{SIMPULAN}

Hasil analisis harga pokok produk menunjukkan nilai yang rendah di tambah laba yang diharapkan oleh pemilik RM Ulu Bete Laut setiap bulan sebesar $50 \%$ per porsi untuk makanan per porsi dan $30 \%$ per gelas untuk minuman buah segar.

Harga jual makanan per unit (per porsi) sebesar $\mathrm{Rp} 12.445$ sedangkan realisasi harga makanan per porsi pada RM Ulu Bete Laut sebesar Rp 22.000,-. Dengan demikian penetapan harga jual sesungguhnya $200 \%$ lebih dari harga pokok yang hanya mencapai Rp 8.297 per porsi.

Harga jual minuman segar sebesar Rp 8.723 per gelas. Realisasi harga yang berlaku pada RM Ulu Bete Laut sebesar Rp 10.000,per gelas. Dengan demikian terdapat kenaikan harga sekitar $140 \%$ dari harga pokok. Jika pemilik Rumah Makan (RM) Ulu Bete Laut tidak mencapai total penjualan di atas, maka dipastikan akan mengurangi jumlah laba usaha dan bahkan dapat menderita kerugian. Hasil analisis profitabilitas pertama berdasarkan data rincian pendapatan, sehingga diperoleh rasio profitabilitas sebesar $30,94 \%$ per bulan, artinya bahwa setiap penjualan Rp 100,mampu memberikan laba usaha sebesar $\mathrm{Rp}$ 30,94 per unit. 
Berdasarkan data harga pokok produk yang dipakai sebagai dasar perhitungan hasil penjualan. Besarnya laba yang diperoleh RM Ulu Bete Laut setiap bulan, dapat dihitung diselisihkan antara hasil penjualan dengan harga pokok. Harga pokok produk yang dipakai sebagai dasar perhitungan harga jual, di peroleh laba usaha sebesar 15,23\%, artinya bahwa setiap penjualan $R p$ 100,mampu memberikan laba usaha sebesar Rp 15,23 per unit.

\section{SARAN}

Disarankan kepada pemilik Rumah Makan Ulu Bete Laut agar menggunakan harga pokok rincian lebih realistis dari pada menggunakan harga pokok taksiran yang memiliki peluang penjualan tidak tercapai dan mengakibatkan kegagalan usaha.

Disarankan kepada pemilik Rumah Makan Ulu Bete Laut agar tetap menggunakan harga pokok yang terinci sebagai dasar perhitungan laba usaha setiap bulannya. Harga jual makanan per porsi sebaiknya di koreksi kembali agar dapat menguasai pasar khusus rumah makan.

\section{DAFTAR PUSTAKA}

Buchari, Alma, (2004), Manajemen Pemasaran dan Pemasaran Jasa. Penerbit: CV. Alfabeta, Bandung

Dharmesta dan Irawan. 2005. Manajemen Pemasaran. Penerbit Liberty, Yogyakarta

Kotler, $\begin{gathered}\text { Philip,dkk. } \\ \text { Pemasaran }\end{gathered} \quad \begin{gathered}2006 . \\ \text { (Edisi }\end{gathered}$
Penerbit: PT. Indeks Kelompok Gramedia, Jakarta.

, dan Amstrong (2004).Dasar-Dasar Pemasaran, Jakarta : Salemba Empat dan Pearson Education Asia.

Mulyadi. 1995. Akuntansi Biaya. Edisi tiga, Penerbit PT.BPFE, Yogyakarta.

Nafarin, M. 2000. "Penganggaran Perusahaan" Penerbit Salemba Empat, Jakarta

Riyanto, Bambang. 1995. "Dasar-dasar Pembelanjaan Perusahaan" Penerbit PT.BPFE, Yogyakarta.

Saladin, Linda, 2006. Perilaku Konsumen dan Pemasaran Strategik. Bandung, CV. Mandar Maju , dan Djaslim, 2003, Unsur-unsur Inti Pemasaran dan Manajemen Pemasaran. Bandung, CV. Mandar Maju.

Sasali, Munawir. 2003. Manajemen Keuangan. Penerbit PT.BPFE, Yogyakarta

Sukirno, Sadono. 2000. "Pengantar Teori Mikro Ekonomi" Penerbit PT. Raja Grakindo Persada, Jakarta.

Swastha, Basu dan Irawan, 2000. Manajemen Pemasaran Modern. Edisi kedua penerbit Liberty, Yogyakarta.

Stanton, 2005.Fundamentals of Marketing, $10^{\text {th }}$ Edition, Singapore : Mc Graw-Hill International.

Soemita. R. 1998. Akuntansi Keuangan. Penerbit PT.BPFE, Yogyakarta.

Suad Husnan dan Enny Pujiastuti, 1998. "Dasar-dasar Manajemen Keuangan" UPP AMP YPKN, Jakarta. 
Vol. 01 No. 02
Umar, Husein. 1994. Dasar-Dasar Pemasaran. Penerbit Erlangga, Jakarta.

www.Google.com dengan penelusuran

Tinjauan Pustaka Karya Tulis Manajemen Pemasaran.

www.garuda-indonesia.com

www.wartaekonomi.com. 